Melinda Rahmawati, Yustiara Nuraini, Bimo Rafi Widianto, Debi Robi Yanti, Sulaeman - Determinasi Konfusianisme dalam Analisis Wacana Kritis Novel Klasik "Journey to the West"

\title{
DETERMINASI KONFUSIANISME DALAM ANALISIS WACANA KRITIS NOVEL KLASIK "JOURNEY TO THE WEST"
}

\section{Melinda Rahmawati}

Universitas Muhammadiyah Prof. Dr. HAMKA, Jakarta, Indonesia

Email : melinda@uhamka.ac.id

\section{Yustiara Nuraini}

Universitas Muhammadiyah Prof. Dr. HAMKA, Jakarta, Indonesia

Email : yustiara@uhamka.ac.id

\section{Bimo Rafi Widianto}

Universitas Muhammadiyah Prof. Dr. HAMKA, Jakarta, Indonesia

Email : bimorafiw@uhamka.ac.id

\section{Debi Robi Yanti}

Universitas Muhammadiyah Prof. Dr. HAMKA, Jakarta, Indonesia

Email : debirobiyanti@uhamka.ac.id

\section{Sulaeman}

Universitas Muhammadiyah Prof.Dr.HAMKA, Jakarta, Indonesia

Email : sulaeman@uhamka.ac.id

\section{Article history:}

Submitted June 30, 2021

Revised July 13, 2021

Accepted Nov 16, 2021

Published Dec 03, 2021

\begin{abstract}
The purpose of research to see the determination formed by Confucianism in critical discourse analysis of the classic novel "Journey To The West". The method used is descriptive qualitative with critical discourse analysis in historical approach (discourse-historical-approach). The result of this research is the presence of a Confucian determination based on the results of critical discourse analysis of discourse-historical-approach to the classic novel "Journey To The West" which is inherent as culture. The conclusion of this research is that there are Confucian values depicted in the classic novel "Journey To The West" through the characterization of the characters in the novel so that Confucianism remains inherent in Chinese society.
\end{abstract}

Keyword: ancient China; confusianism; critical discourse analysis; eastern philosophy; journey to the west 
Melinda Rahmawati, Yustiara Nuraini, Bimo Rafi Widianto, Debi Robi Yanti, Sulaeman - Determinasi Konfusianisme dalam Analisis Wacana Kritis Novel Klasik "Journey to the West"

\begin{abstract}
ABSTRAK
Tujuan penelitian ini untuk melihat determinasi yang dibentuk oleh konfusianisme dalam analisis wacana kritis atas novel kalsik "Journey To The West". Metode digunakan deskriptif kualitatif dengan analisis wacana kritis dalam pendekatan sejarah (discourse-historical-approach). Hasil dari penelitian ini hadirnya sebuah determinasi konfusianisme berdasarkan hasil analisis wacana kritis discourse-historical-approach terhadap novel klasik "Journey To The West" yang melekat sebagai budaya. Kesimpulan dari Penelitian ini terdapat nilai Konfusianisme yang digambarkan dalam novel kasik "Journey To The West" melalui perwatakan tokoh dalam novel tersebut sehingga Konfusianisme tetap melekat dalam Masyarakat Tionghoa.
\end{abstract}

Kata kunci : China kuno; konfusianisme; analisis wacana kritis; filsafat timur; journey to the west

\title{
PENDAHULUAN
}

Masyarakat Tionghoa menjadi salah satu masyarakat yang tersebar di seluruh dunia. Masyarakat Tionghoa dari generasi ke generasi tidak pernah melupakan ajaran kepercayaan dari nenek moyang mereka, yakni konfusianisme. Ajaran ini memang menjadi salah satu ajaran tertua yang berasal dari Tiongkok (China). Berisikan sebuah pemikiran bijak dari seorang Kun Fu Tzu, seorang filsuf yang melakukan pengamatan atas kekacauan yang terjadi di Masa Dinasti Chou (722-221 SM). Konfusianisme yang dibawakan oleh Kun Fu Tzu berpijak pada budaya tradisional Cina khususnya sejarah, sastra, musik, dan ritual dari Masa Dinasti Chou Barat (1050-770 SM) (Asruchin, 2018).

Konfusianisme menjadi sangat melekat dan menjadi identitas budaya dari Masyarakat Tionghoa karena berakar pada pemikiran filsafat kebijaksanaan yang humanis . Filsafat kebijaksanaan ini hadir ketika pada masa Dinasti Chou mengembangkan sebuah doktrin bahwa mereka telah mendapat mandat dari langit, sehingga yang menjadi pemimpin harus bertanggung jawab membimbing masyarakatnya melalui undang-undang moral yang menyatakan bahwa nasib mereka ditentukan dari cara hidup serta aturan yang diberlakukannya. Sebab itu manusia harus memiliki sifat setia, berbakti, 
memiliki pengendalian diri, dan dapat menerima sebuah kebenaran. Sifat tersebut harus dapat mengantarkan manusia pada kemuliaannya menjadi manusia yang memiliki kebajikan, kebenaran, taat pada ritual dan upacara, berpengetahuan, dan memiliki integritas.

Konfusianisme ini menyebar dengan berbagai cara dan media yang melekat menjadi sebuah budaya dari Masyarakat Tionghoa, baik melalui keluarga, pengajaran, hingga sastra klasik. Pada Pertengahan Abad ke- 16, Sastrawan klasik Wu Cheng'en Menuliskan sebuah novel yang kini kita kenal dengan "Journey To The West". Novel ini menjadi salah satu dari beberapa karya sasta yang menginterpretasikan mengenai Konfusianisme. Melalui Tokoh Sun Go Kong tergambarkan watak asli manusia yang bercampur dengan nafsu, sedangkan melalui Tokoh Biksu Tong tergambarkan watak seorang biksu yang teguh dalam memegang ajarannya namun menghadapi persoalannya sendiri saat menghadapi tipuan dari para siluman, serta tokoh-tokoh lainnya yang menginterpretasikan bagian-bagian dari sifat buruk dan baik manusia. Konfusianisme menjadi lekat dan menyatu dengan budaya Masyarakat Tionghoa salah satunya karena penyebaran agamanya dengan melalui novelnovel klasik. Contoh salah satu novel klasik "Journey To The West" ini.

Tujuan dari penelitian ini adalah untuk mengetahui secara dalam mengenai Konfusianisme dan Representasinya dalam sebuah Novel Klasik dari pertengahan abad ke - 16 yang berjudul "Journey To The West" karya Wu Cheng'en. Konfusianisme tidak pudar dan hilang walaupun sudah ada lebih dari 25.000 tahun lamanya pada Peradaban Cina Kuno. Salah satu faktor melekatnya ini karena nilai-nilai yang diajarkan tidak hanya melalui tutur dari keluarga, namun juga terdapagt berbagai karya sastra yang memberikan penggambaran mengenai nilai-nilai dalam Konfusianisme.

Penelitian sebelumnya banyak berbicara mengenai Konfusianisme sebagai salah satu yang telah diwariskan sejak lama hingga menjadi sebuah identitas dari Masyarakat Tionghoa. Namun belum ada yang mengaitkan Konfusianisme tersebut dengan salah satu novel klasik dari Tiongkok. Secara 
Melinda Rahmawati, Yustiara Nuraini, Bimo Rafi Widianto, Debi Robi Yanti, Sulaeman - Determinasi Konfusianisme dalam Analisis Wacana Kritis Novel Klasik "Journey to the West"

seksama novel-novel klasik tersebut menyiratkan nilai-nilai dari Konfusianisme. Konfusianisme yang menyebar dan bertahan selain melalui budaya tutur yang diwariskan dari para leluhur, terdapat upaya penyebaran melalui karya-karya sastra klasik dengan penggambaran tokoh mitologi yang dipercayai oleh Masyarakat Tionghoa hingga hari ini.

\section{TEORI DAN METODE PENELITIAN}

Penelitian ini menggunakan teori interpretatif simbolik yang dikemukakan oleh Clifford Geertz. Menurut Geertz, kebudayaan merupakan jaringan dari simbol-simbol yang mengandung makna bagi suatu masyarakat. Makna dari simbol yang dibentuk tersebut kemudian ditafsirkan oleh masyarakat dari setiap kegiatan yang mereka lakukan (Ramadhani, 2018). Kebudayaan sendiri terdiri dari rencana, resep, aturan, dan instruksi yang berfungsi untuk mengatur tingkah laku manusia (Lestari \& Indarti, 2018). Teori ini secara khusus mengkaji mengenai hakikat pentingnya makna bagi kehidupan manusia (Laila, 2017).

Penelitian yang dilakukan berbentuk Penelitian Kualitatif Deskriptif dikarenakan peneliti tidak melakukan perubahan atas objek penelitan dan hanya menghadirkan penggambaran atas hal yang terdapat dalam objek penelitian (Arikunto, 2019). Penelitian ini menitikan pada kajian studi pustaka berdasarkan buku-buku dan artikel ilmiah yang diterbitkan dari tahun 2017 2021. Khususnya melakukan analisis psutaka terhadap novel klasik "Journey To The West" sebagai salah satu bentuk determinasi ajaran Konfusianisme hingga menjadikannya sebagai falsafah hidup Masyarakat Tionghoa hingga hari ini. Konfusianisme sebagai salah satu ajaran tertua dalam peradaban manusia yang telah melekat sebagai budaya dari Masyarakat Tionghoa tentu mengandung nilai-nilai yang kuat, tidak hanya sekedar sebuah nilai budaya yang diwariskan oleh leluhur namun mengandung sebuah pemikiran filsafat kebijaksanaan mengenai aturan moral hidup di dunia. Inilah yang membuat Konfusianisme melekat sebagai falsafah hidup dan budaya Masyarakat Tionghoa. 
Triangulasi data yang dilakukan dalam penelitian ini untuk mendukung dan memperlihatkan ukuran yang tidak tergantung atau bertentangan, melainkan menyediakan, membuktikan, serta melihat terjadinya sebuah konflik kepentigan kognitif yang potensial (Miles, Matthew B., 1992). Dalam penelitian ini, data-data yang dikumpulkan dari berbagai literasi seperti buku, jurnal, laman daring dari media informasi terpercaya, dan hasil penelitian lainnya yang membahas mengenai Konfusianisme dan secara khusus menghadirkan analisis dari novel klasik "Journey To The West" menguatkan bahwa hadirnya Konfusianisme sebagai upaya dari pembentukan kode etik atau cara hidup Masyarakat Tionghoa yang digagas oleh Kung Fu Tzu (Kong $\mathrm{Hu} \mathrm{Cu}$ ) memang melekat erat karena adanya kesepamahaman dalam falsafah hidup dan dapat digambarkan melalui mitologi yang diyakini oleh Masyarakat Tionghoa sebagai penggambaran nyata dari implementasi falsafah tersebut dalam hidup manusia.

Metode penelitian yang digunakan adalah metode Analisis Wacana Kritis dengan konsep Discourse Historical-Approach atau dikenal dengan pendekatan wacana berdasarkan pada sejarah (Haryatmoko, 2019). Metode ini secara khusus membedah literasi-literasi yang berkaitan dengan ajaran Konfusianisme dalam novel klasik "Journey To The West". Novel ini menjadi contoh utama karya sastra klasik yang memberikan penggambaran mengenai implementasi ajaran Konfusianisme. Wacana kritis yang dibentuk dalam penelitian ini lebih bercorak pada sejarah dari terbentuknya ajaran Konfusianisme hingga ajaran tersebut tergambarkan dalam sebuah novel klasik yang menjadi salah satu upaya ajaran Konfusianisme ini masih ada sebagai falsafah hidup dari Masyarakat Tionghoa.

\section{HASIL DAN PEMBAHASAN}

\section{Biografi Kun Fu Tzu dan Perkembangan Pada Dinasti Chou (722-221 SM)}

Bangsa Cina Kuno dikenal mempunyai kepercayaan bersifat Politheisme (menyembah banyak dewa). Mereka memuja dewa-dewa yang dianggap 
Melinda Rahmawati, Yustiara Nuraini, Bimo Rafi Widianto, Debi Robi Yanti, Sulaeman - Determinasi Konfusianisme dalam Analisis Wacana Kritis Novel Klasik "Journey to the West"

sebagai sumber kekuatan antara lain Dewa Feng-Fa (dewa angin), Dewa LeiShih (dewa taufan). Kedua dewa ini digambarkan dalam wujud ular naga besar. Dalam keyakinan Masyarakat Tionghoa, kekuatan keseimbangan tertinggi alam terletak di langit atau disebut dengan Dewa Langit Thian (Tuhan) yang dianggap kuasa yang menciptakan segalanya. Thian Sangat dihormati dan dipercaya juga sebagai penentu kebahagiaan dan nasib manusia. Keyakinan keagamaan Orang Cina di bagi menjadi dua yaitu tradisi besar dan tradisi kecil, tradisi besar terdiri dari praktek-praktek keyakinan keagamaan yang berdasarkan sumber tertulis dan menjadi sebuah tradisi turun temurun. Hal ini tercakup Taoisme, Konfusianisme, Budhanisme. Sedangkan tradisi kecil meliputi sebelum ajaran agama tradisi besar hadir. masyarakat mengenal dengan agama rakyat yang mereka jadikan pendoman sehari-hari (Husna, 2020; Tenggok, 2017).

Perlahan Politheisme ini menjadi bagian dari budaya Masyarakat Tionghoa hingga hari ini. Walaupun kini masyarakat tidak lagi banyak melakukan persembahan para dewa, namun budaya untuk menyediakan altar persembahan tetap ada dan diturunkan dari generasi ke generasi. Terbentuknya Konfusianisme tidak lepas dari pemikiran filosofis yang berpijak pada sastra dan budaya Masyarakat Tionghoa yang telah diturunkan dari para leluhur (Plc, 2006). Pada masa Dinasti Chou Timur ini, banyak sekali praktek ketidakjujuran khususnya dalam jajaran pemerintahan istana. Hal Ini menimbulkan berbagai permasalahan yang kompleks ditengah masyarakat seperti kemiskinan, korupsi, kriminalitas, dan sebagainya. Kemerosotan moral para pejabat pemerintahan ini yang akhirnya di kritik keras oleh Kun Fu Tzu dalam Konfusianisme yang dikembangkannya. Konfusianisme tumbuh dan berkembang dengan pemikiran kebijaksanaan yang telah diturunkan dari leluhur.

Konfusianisme dibawa oleh seorang Filsuf Cina Kung Fu Tzu. Nama tersebut merupakan panggilan nama dalam Bahasa Tionghoa, sedangkan dalam Bahasa orang-orang barat Kung Fu Tzu lebih dikenal dengan nama 
Konfusius. Kung Fu Tzu lahir pada 551 SM di daerah Lu, Kung Fu Tzu lahir dimasa Dinasti Chou Timur (722-221 SM) (Agung, 2018). Kung Fu Tzu hidup se-zaman dengan filsuf Lao-Tzu, seorang filsuf yang mengajarkan Taoisme dan menulis Kitab Kebajikan Tao Te Ching. Dalam perjalanan pengajarannya, Kung Fu Tzu sejatinya merupakan rakyat biasa yang masih berdarah bangswan (aristokrat) (Meher, 2019; Rozie, 2012). Sedari kecil Kung Fu Tzu sudah mempelajari dan tertarik terhadap ritual upacara-upacara yang berhubungan dengan ritual persembahan kepada leluhur. Awal mula dalam karier Kung Fu Tzu tidak langsung menjadi seorang guru, tetapi bekerja di dalam pemerintahan sebagai Pengelola Gudang Gandum sekitar tahun 530 SM. Kung Fu Tzu bekerja dengan tekun dan bertangung jawab atas pekerjaannya menjaga gudang pangan tersebut dari serangan jamur atau parasite. Dua tahun selanjutnya Kung Fu Tzu mendapatkan kenaikan pangkat menjadi Pengelolah kawanan Sapi dan Domba Milik Negara.

Belajar dari pekerjaan sebelumnya Kung Fu Tzu sangat memperhatikan lebih terhadap domba dan sapi yang menjadi tanggung jawabnya (Meher, 2019). Untuk bekerja di dalam pemerintahan saat itu sangat sulit walupun memiliki pendidikan yang baik. Hal ini disebabkan oleh pemberlakuan kasta sosial antara kaum bangswan dengan kaum rakyat biasa. Struktur sosial masyarakat tertutup yang terapkan oleh Masyarakat Tionghoa masa itu telah memberi batas interaksi yang nyata. Hadirnya pembatasan ini menghadirkan model penguasaan feodalistik yang menindas dan tidak berkemanusiaan.

Pada dua tahun setalah pengangkatan sebagai Pengelola Kawanan Sapi Milik Negara, Kung Fu Tzu mendapatkan kabar duka atas wafatnya sang ibu. Pada saat itu, terdapat peraturan bahwa dalam masa duka pekerja tidak dikerjakan dahulu. Hingga ketika selesai masa berkabung, Kung Fu Tzu memutuskan untuk meninggalkan pekerjaannya karena kurang menghidupi kebutuhan keluarganya. Untuk memenuhi kebutuhan keluarga, Kung Fu Tzu mulai membuka sekolah sendiri dan memulai karir barunya menjadi guru. Selain mampu memiliki keuangan yang lebih baik, Kung Fu Tzu juga dapat 
Melinda Rahmawati, Yustiara Nuraini, Bimo Rafi Widianto, Debi Robi Yanti, Sulaeman - Determinasi Konfusianisme dalam Analisis Wacana Kritis Novel Klasik "Journey to the West"

membagi kecerdasan yang dimiliki. Kung Fu Tzu sangat mahir dalam ilmu sejarah kuno, musik dan ritual-ritual leluhur meskipun dari kasta yang rendah. Tetapi Kung Fu Tzu tidak patah semangat untuk terus belajar hingga menjadi seorang yang berintelektual tinggi di Negara Bagian Lu. Kung Fu Tzu belajar musik dengan gurunya, Xiang dan menghabiskan masa mudanya untuk mempelajari tentang sejarah dan ritual-ritual persembahan.

\section{Sejarah Konfusianisme}

Kung Fu Tzu dalam pemikiran filosofinya sangat menekankan kepada sebuah kasih sayang serta rasa hormat kepada semua lapisan masyarakat baik lapisan atas maupun bawah dan menekankan kepada pendidikan sebagai sebuah sarana untuk membuat serta mengembangkan pemikiran dan menumbuhkan karakter. Ajarannya tentang kemanusiaan yang menjelaskan bahwa pada dasarnya manusia itu semuanya baik akan tetapi akan tetapi adanya nafsu yang ada di dalam tubuh manusia menjadikan manusia menjadi tidak baik. Ajaran Kun Fu Tzu dapat disebut sebagai Ju Chia (Kung Chia), atau secara luas orang-orang menyebut Konfusianisme. Dasar pokok ajaran Konfusianise ini terletak pada $L i$, Ren dan I (Singgih, 2016). Li ialah sebuah adat istiadat menurut Kung Fu Tzu adat istiadat haruslah di pengang teguh terlebih dahulu supaya masyarakat dapat tentram, adat istiadat ini meliputi cara orang harus mengetahui dirinya pada tempatnya dengan orang yang paling tinggi menghormati seorang yang memiliki kedudukan yang tinggi, Ren adalah Kemanusiaan dan $I$ perikeadilan apabila manusia memiliki kemanusiaan dan keadilan maka menurut Kung Fu tzu apabila manusia. memiliki Li, Ren dan I maka didunia ini akan damai tidak adanya peperangan antar umat.

Dalam membuka sekolah, Kung Fu Tzu tidak sembarangan menerima murid baru di sekolahnya. Kung Fu Tzu menetapkan kriteria tersendiri dalam memilih muridnya. Pertama, Kung Fu Tzu hanya memilih murid yang cerdas dan antusias. Kedua, Kung Fu Tzu tidak memandang kasta dalam memilih murid baik itu kasta tertinggi sampai dengan kasta terendah sekalipun, 
ataupun dari latar belakang manapun tidak terpatok pada kaum bangswan saja (Meher, 2019; Zarkasih, 2014). Dari keriteria tersebut Kung Fu Tzu menginginkan murid yang benar-benar mau belajar dan bersunguh-sunguh dalam menuntut ilmu pengetahuan yang diberikan kepada muridnya. Tidak perduli murid tersebut berasal dari kasta sosial apapun. Kung Fu Tzu tetap menerima murid yang bukan berasal dari kaum bangsawan dikarenakan asal usul Kung Fu Tzu sendiri dari rakyat biasa (walaupun ada garis keturunan bangswan) yang menjadikan Kun $\mathrm{Fu} \mathrm{Tzu}$ mengetahui akan kesenjangan pendidikan antara rakyat biasa dengan para anak-anak dari kaum bangsawan.

Kung Fu Tzu dalam pemikiran filosofinya sangat menekankan kepada sebuah kasih sayang serta rasa hormat kepada semua lapisan masyarakat baik lapisan atas maupun bawah dan menekankan kepada pendidikan sebagai sebuah sarana untuk membuat serta mengembangkan pemikiran dan menumbuhkan karakter (Asruchin, 2018; Li, 2007). Ajarannya tentang kemanusiaan, menjelaskan bahwa pada dasarnya manusia itu semuanya baik akan tetapi akan tetapi adanya nafsu-nafsu yang ada di dalam tubuh manusia menjadikan manusia menjadi tidak baik. Ajaran Kung Fu Tzu dapat disebut sebagai Ju Chia (Kung Chia), atau secara luas diartikan Konfusianisme. Dasar pokok Konfusianise ini terletak pada Li, Ren dan Yi. Li Menurut Kung Fu Tzu merupakan Kesusilaan atau adat istiadat yang harus di pengang teguh terlebih dahulu supaya masyarakat dapat tentram, adat istiadat ini meliputi cara orang harus mengetahui dirinya pada tempatnya dengan orang yang paling tinggi menghormati seorang yang memiliki kedudukan yang tinggi. Ren adalah Kemanusiaan. Serta, $Y i$ adalah Perikeadilan. Manusia memiliki rasa kemanusiaan dan keadilan dalam diri, maka dunia ini akan damai tidak adanya peperangan antar umat.

\section{Konfusianisme Menjadi Falsafah Hidup Masyarakat Tionghoa}

Jauh sebelum lahirnya Konfusianisme, kepercayaan yang dianut Masyarakat Tiongkok adalah Taoisme dan Buddha. Namun secara sederhana, 
Melinda Rahmawati, Yustiara Nuraini, Bimo Rafi Widianto, Debi Robi Yanti, Sulaeman - Determinasi Konfusianisme dalam Analisis Wacana Kritis Novel Klasik "Journey to the West"

ketiga ajaran ini lahir ditengah kekacauan masyarakat namun ketiganya tetap memiliki perbedaan. Kepercayaan Taoisme dan Buddha lebih merujuk kepada pemujaan alam, penghormatan kepada leluhur dan pemujaan terhadap dewa dewa langit. Dalam suasana inilah melahirkan kepercayaan Kong $\mathrm{Hu} \mathrm{Cu}$ dengan istilah Tsin atau dalam bahasa latin disebut Confusius. Konfusianisme ini lebih merjuk kepada filsafat mengenai kode etik maunisia yang terletak pada etika, susila dan kehidupan moral (Pattiasina, 2021; Plc, 2006). Para pengikut ajaran Konfusianisme ini secara umum menolak bahwa Konfusianisme ini merupakan sebuah agama, melainkan sebuah kode etik atau hukum moral yang berpijak pada kebijaksanaan para leluhur terdahulu. Hubungan sosial dan moral antara penguasa dengan yang dikuasai harus saling seimbang dan melengkapi dengan kebijaksanaan. Begitupula dengan hubungan antara orang tua dan anak, harus adanya penggambaran keteladanan dan kepatuhan pada orang tua. Hubungan antara suami dan isteri haruslah selaras dan menutupi kekurangan diri masing - masing pasangan karena bersama pasangan kita akan menjadi diri sendiri. Hingga hubungan antara saudara tua dan saudara muda serta hubungan antar teman haruslah saling mengerti dan membantu dalam kesulitan.

Sebagai salah satu ajaran tertua yang berkembang di daratan Tiongkok, Konfusianisme tentu telah melekat sebagai falsafah hidup masyarakat yang dijunjung dari generasi ke generasi dan menjadi pedoman hidup secara keseluruhan. Konfusianisme secara spesifik mencatat pasang surut sejarah dari kedinastian Tiongkok dan perkembangannya diberbagai bidang, termasuk ajaran Konfusianisme itu sendiri (Muas, 2020; Rosidi, 2015). Konfusianisme pernah di tolak dan dilarang penyebarannya pada masa Kaisar Qin Shi-Huang dari Kekaisaran Dinasti Qin (221-207 SM), namun pada periode-periode kekaisaran lainnya ajaran Konfusianisme ini sangat diterima dan menjadi dasar aturan hidup atau falsafah hidup dari Masyarakat Tionghoa berdampingan dengan Taoisme. Sampai sekitar abad ke-2 SM, masuklah ajaran Buddha yang dibawakan oleh para biksu dari India dan akhirnya Masyarakat Tionghoa 
menjalankan 3 ajaran tersebut dalam 1 ajaran kesatuan yang disebut dengan San Jiao atau secara khusus dikenal dengan Tridharma.

Ren, $L i$, dan Yi ditopang kembali oleh $\mathrm{C} i$ dan Xin sebagai penguat dari pokok Ajaran Konfusianisme ini. Ci yang berarti Kebijaksanaan dan Xin yang berarti Kejujuran mengajarkan bahwa keteraturan yang tercipta baik antara atasan dengan bawahan, suami - isteri, antar teman, maupun antar saudara harus ada kebijaksanaan dan mengedepankan arti penting sebuah kejujuran. Hal ini dimaksudkan agar terciptanya sebuah keteraturan dalam tatanan sosial yang dimulai dari lingkup kecil, yakni keluarga (Cangianto, 2015; Hartati, 2016). Kun Fu Tzu menilai, setiap manusia yang terikat dalam satu sistem masyarakat harus saling memiliki etika (nilai) dan moral yang diatur didalam sebuah norma sosial. Keteraturan ini dapat membentuk sebuah tatanan sosial yang stabil dan kuat saat menghadapi berbagai bahaya baik bahaya laten yang menyerang dari dalam maupun bahaya nyata yang menyerang dari luar (peperangan). Keseimbangan yang dihadirkan ini menjadikan Konfusianisme mampu menjadi falsafah hidup dari Masyarakat Tionghoa dan tetap relevan dalam berbagai zaman hingga saat ini.

Etika dan Moralitas yang ditekankan dalam ajaran Konfusianisme ini memberikan kita pengajaran bahwa untuk menciptakan sebuah perdamaian di dunia, manusia harus saling menghormati dan menghargai. Dengan keprihatinan atas keadaan negeri khususnya pada masa Dinasti Chou Timur (722-221 SM), Konfisianisme menekankan hadirnya kebijaksanaan dan kepatuhan secara nilai dan norma agar tercipta sebuah keteraturan ditengah masyarakat (Asruchin, 2018; Li, 2007). Bagi para pengikut Konfusianisme, pemerintah dan masyarakat mmapu mencapai sebuah ketentraman dan keharmonisan dalam hubungan sosialnya jika seluruh elemen yang terlibat saling memahami kekurangan diri dan bersedia tumbuh bersama. Secara bersama menghindari sifat negatif yang dapat muncul dari perilaku masingmasing. Pengaturan hubungan yang efektif dalam menciptakan tatanan keteraturan ini dimulai dari keluarga. Hubungan antara suami-isteri harus 
Melinda Rahmawati, Yustiara Nuraini, Bimo Rafi Widianto, Debi Robi Yanti, Sulaeman - Determinasi Konfusianisme dalam Analisis Wacana Kritis Novel Klasik "Journey to the West"

didasarkan pada rasa Kejujuran (Xin) dan Keadilan (Yi) tanpa menghakimi kekurangan masing-masing. Berlanjut pada hubungan antar saudara yang harus dengan rasa Kemanusiaan ( $\operatorname{Ren})$, memiliki aturan yang tidak melanggar persoalan pribadi/adat-istiadat $(L i)$ sehingga hubungan persaudaraan yang terjalin tidak saling merugikan. Hingga dalam tatanan kompleks antara Penguasa dan Rakyat, seorang penguasa haruslah mampu menghadirkan sebuah kestabilan sosial yang didalamnya terkadung rasa Kemanusiaan, menjunjung tinggi Kesusilaan/adat-istiadat, menghadirkan sebuah Keadilan dan Kejujuran, hingga terciptanya sebuah Kebijaksanaan.

\section{Analisis Wacana Kritis Konfusianisme Dalam Novel "Journey To The West"}

Novel "Journey To The West" karya Wu Cheng'en ini memang tidak asing dalam Sastra Tionghoa Kuno. Novel ini menjadi salah satu karya yang berkisah tentang sebuah tokoh fiktif siluman monyet bernama Sun-Go-Kong yang berguru pada seorang biksu bernama Tong atau Tang Sanzang. Wu Cheng'en yang pada tahun 1590-an terkenal sebagai sastrawan yang terkenal sangat Konfusianisme. Termasuk salah satu karya nya ialah novel ini yang diterbitkan pada 1592. Dikutip dari cerita bagian 68 dari Novel "Journey To The West" sebagai berikut (Cheng'en, 2008) :

when good is right all causes disappear;

its fame is spread through all four continents.

in the light of wisdom they climb the other shore;

soughing dark clouds are blown from the edge of the sky.

Diterjemahkan :

"Ketika kebaikan adalah benar semua penyebab menghilang;

ketenarannya tersebar di keempat benua.

dalam terang kebijaksanaan mereka mendaki pantai lain;

awan gelap yang menderu-deru dihembuskan dari tepi langit."

Dalam kutipan tersebut mengisyaratkan bahwa ketika sebuah seseorang berbuat kebaikan yang dilakukan ternyata menjadi penyebab dari hilangnya sesuatu yang dimiliki atau akan dimiliki, maka peristiwa tersebut akan 
langsung tersebar secara menyeluruh melalui perkabaran antar individu. Mereka yang melakukan kebaikan tersebut kembali berjalan ke tujuan yang lain dengan kebijaksanaan yang mereka miliki, perjalanan kehidupan mereka selanjutnya ditemani oleh suasana hitam cobaan hidup dan rintangan lain yang telah siap untuk mereka lewati.

Pemaknaan serupa juga telah dituliskan dalam buku ajaran Konfusianisme yang ditulis oleh para murid Konfusius. Dikutip langsung dari Konfusius : The Analek Buku IV Le Jin Bab XI, sebagai berikut (Konfusius, 2018) :

"Sang guru berkata, 'orang yang mulia memikirkan kebajikan; orang bermoral rendah memikirkan kenyamanan. Orang yang mulia memikirkan sanksi-sanksi hukum; orang bermoral rendah memikirkan imbalan-imbalan yang mungkin mereka terima.' "

Dapat kita amati kembali bahwa dalam kebaikan yang kita lakukan belum tentu akan sepenuhnya menghasilkan kebaikan yang bermanfaat bagi sekitar kita. Diperlukan sebuah kebijaksanaan yang tercipta dari $\mathrm{Li}$ (Adat Istiadat/Norma Sosial), Ren (Peri Kemanusiaan) dan Yi (Keadilan), lalu di tumpukan kembali pada Ci (Kebijaksanaan) dan Xin (Kejujuran). Ci akan membantu menjadikan manusia yang menjalani kehidupannya dengan lebih rendah hati dan selalu memaafkan kesalahan orang lain serta diri kita sendiri. Nilai kehidupan yang dapat diinterpretasikan dalam kehidupan sehari-hari adalah kita harus mengerti satu hal mendasar, bahwa kadang perbuatan baik yang kita lakukan justru menyebabkan kita akan kehilangan sesuatu yang kita miliki atau akan kita miliki. Tetaplah berbuat baik dan berjalan walaupun di lingkungan yang berbeda, karena cobaan hidup dan rintangan kehidupan telah siap menanti kita. Kebijaksanaan diri akan membawa kita pada keadaan moralitas saat kita mampu memaafkan kesalahan orang lain, diri kita sendiri, dan menjadikan diri kita rendah hati ditengah keberadaan kita di tengah masyarakat. 
Melinda Rahmawati, Yustiara Nuraini, Bimo Rafi Widianto, Debi Robi Yanti, Sulaeman - Determinasi Konfusianisme dalam Analisis Wacana Kritis Novel Klasik "Journey to the West"

Dalam bagian 77 dari cerita novel tersebut kembali tersirat pemaknaan mengenai ajaran moral dalam Konfusianisme, kutipan cerita sebagai berikut (Cheng'en, 2008) :

no thread can be spun from a single strand nobody can clap with a single hand

Diterjemahkan :

"tidak ada benang yang dapat dipintal dari satu untai tidak ada yang bisa bertepuk tangan dengan satu tangan"

Dalam kutipan tersebut mengisyaratkan bahwa manusia itu sejatinya tidak dapat menjalani kehidupannya sendirian. Manusia itu hidup secara berdampingan dan saling membutuhkan satu dengan yang lain. Jika yang lain meninggalkan, tentu manusia akan merasa kesepian dan sendirian. Akan banyak sekali kebutuhan baik dari segi sosial, psikologi, dan sebagainya yang tidak dapat terpenuhi secara optimal hanya karena manusia hidup seorang diri. Dalam situasi apapun manusia tetap membutuhkan manusia lainnya.

Pemaknaan serupa juga telah dituliskan dalam buku Konfusius : The Analek. Dikutip langsung dari Konfusius : The Analek Buku IV Le Jin Bab XXV dan Bab XXVI, sebagai berikut (Konfusius, 2018) :

Sang Guru Berkata 'kebajikan tidak berdiri sendiri. Ia yang mempraktekannya akan memiliki tetangga.'

Berlanjut pada Bab XXVI :

Tsze-yu berkata, 'dalam melayani seorang pangeran, sering membantah mengarah pada rasa malu. Diantara teman, sering mencela akan merenggangkan persahabatan.'

Dapat kita amati kembali bahwa manusia memang tidak diciptakan untuk hidup sendiri. Sebagai makhluk sosial, manusia membutuhkan adanya interaksi dan komunikasi dengan manusia lain tanpa terkecuali dengan asalan apapun. Jika manusia melakukan kebajikan pada manusia lain, tentu manusia tersebut akan lebih banyak memperoleh teman dimanapun ia berada. Setiap manusia harus melaksanakan inti ajaran Konfusianisme yakni Li (Adat Istiadat/Norma Sosial), Ren (Peri Kemanusiaan) dan Yi (Keadilan), yang kemudian tumpukan kembali pada Ci (Kebijaksanaan) dan Xin (Kejujuran) 
Melinda Rahmawati, Yustiara Nuraini, Bimo Rafi Widianto, Debi Robi Yanti, Sulaeman - Determinasi Konfusianisme dalam Analisis Wacana Kritis Novel Klasik "Journey to the West"

dengan seimbang dan relevan sesuai masa nya. Dengan menjalankan inti ajaran Konfusianisme tersebut manusia yang menjalankannya akan mampu menciptakan sebuah lingkungan yang stabil dan harmonis. Perbedaan yang hadir tidak menyurutkan sebuah kebajikan yang dijalankan secara komprehensif di berbagai unsur.

Walaupun kini ajaran Konfusianisme telah secara penuh ditetapkan sebagai falsafah negara dari RRT (Republik Rakyat Tiongkok) dan telah masuk dalam setiap sendi kehidupan Masyarakat Tiongkok hingga hari ini, menjadikan ajaran Konfusianisme ini semakin melekat sebagai budaya khas dari Masyarakat Tionghoa (Asruchin, 2018; Hartati, 2016). Meskipun pada masa Dinasti Qin (221-207 SM) Ajaran Konfusianisme ini pernah dilarang penyebarannya dan pengajarannya hingga pada masa reformasi Mao Zedong para pengikut ajaran ini menyingkir ke Pulau Formosa (Kini Taiwan), Ajaran Konfusianisme tetap melekat sebagai budaya yang dibawa oleh Masyarakat Tionghoa dimanapun mereka berada. Mereka menanggap Ajaran Konfusianisme ini sebagai bagian dari warisan leluhur mereka yang harus dijaga dan dipertahankan walau sudah berbeda generasi. Ajaran Konfusianisme yang dipegang teguh sebagai warisan leluhur yang tidak luntur oleh perubahan zaman, membuktikan bahwa Ajaran Konfusianisme ini dapat berkembang di berbagai zaman. Bahkan kini Ajaran Konfusianisme menjadi pilar penting dari dalam tatanan bernegaran RRT (Republik Rakyat Tiongkok).

Merujuk kembali dalam Ajaran Konfusianisme, bahwa semua manusia sejatinya ketika lahir ke dunia telah membawa kodrat sebagai makhluk yang hakikatnya baik. Kodrat tersebut disebut Xing atau watak sejati. Xing merupakan benih yang harus hadir dalam diri. Dalam badan manusiawi, tentu terdapat Xing utama tidak lain adalah hati yang mengandung cinta kasih. Xing mampu berkembang dan menjadikan manusia sebagai makhluk yang sempurna (secara moral), manusia diharuskan selalu dalam sebuah jalan kebenaran (jalan suci) (Husna, 2020; Zarkasih, 2014). Dengan menjalankan 5 (lima) ajaran dasar dari Konfusianisme ini, manusia akan mampu 
Melinda Rahmawati, Yustiara Nuraini, Bimo Rafi Widianto, Debi Robi Yanti, Sulaeman - Determinasi Konfusianisme dalam Analisis Wacana Kritis Novel Klasik "Journey to the West"

memunculkan Xing (watak sejati) nya. Xing yang dimiliki akan mengantarkan manusia pada sebuah kebajikan yang sempurna (secara moral). Tentu untuk mencapai hal tersebut manusia harus berada pada sebuah jalan kebenaran (jalan suci) yang berpedoman pada 5 (lima) dasar Ajaran Konfusianisme yakni ; Li (Adat Istiadat/Norma Sosial), Ren (Peri Kemanusiaan) dan Yi (Keadilan), yang kemudian tumpukan kembali pada Ci (Kebijaksanaan) dan Xin (Kejujuran). 5 (lima) dasar Ajaran Konfusianisme ini menjadi rambu-rambu dalam norma kehidupan masyarakat khususnya Masyarakat Tionghoa dalam melakukan interaksi sosial.

\section{SIMPULAN}

Ajaran Konfusianisme telah melekat sebagai budaya dari Masyarakat Tionghoa dan selalu diturunkan hingga ditetapkan sebagai norma yang harus dijaga. Walaupun Masyarakat Tionghoa telah berkembang dan meluas ke berbagai negara dan sudah banyak dari keturunannya yang berpindah keyakinan agama, namun Ajaran Konfusinasime ini tetap diturunkan dari generasi ke generasi sebagai sebuah aturan utama yang dilakukan dalam keluarga. Salah satu penggambaran implementasi Ajaran Konfusianisme ini dengan melalui sastra klasik yang salah satunya adalah novel karya Wu Cheng'en tahun 1590-an berjudul "Journey To The West". Novel klasik tersebut menggunakan tokoh fiktif siluman monyet bernama Sun-Go-Kong yang berguru pada seorang biksu bernama Tong atau Tang Sanzang. Melalui peran dari tokoh fiktif ini Ajaran Konfusianisme disiratkan secara epik dan mudah untuk masuk dalam pemahaman Masyarakat Tionghoa. Hingga saat ini, Masyarakat Tionghoa tidak asing dengan adanya Novel Klasik karya Wu Cheng'en tahun 1590-an berjudul "Journey To The West" ini, tekhusus pada tokoh utamanya yakni siluman monyet bernama Sun-Go-Kong. Novel ini menjadi sangat berkesan bagi Masyarakat Tionghoa, serta Ajaran Konfusianisme yang digambarkan dalam alur cerita novel tersebut membuat Masyarakat Tionghoa umumnya lebih mudah melihat implementasi nilai dari 
Melinda Rahmawati, Yustiara Nuraini, Bimo Rafi Widianto, Debi Robi Yanti, Sulaeman - Determinasi Konfusianisme dalam Analisis Wacana Kritis Novel Klasik "Journey to the West"

Ajaran Konfusianisme ini. Sehingga Ajaran Konfusianisme ini masih ada dan melekat sebagai norma utama yang berlaku dalam lingkungan Masyarakat Tionghoa.

\section{DAFTAR PUSTAKA}

Agung, L. (2018). Sejarah Asia Timur 1. PT. Kompas Media Nusantara.

Arikunto, S. (2019). Prosedur penelitian: suatu pendekatan praktik. Penerbit Rineka Cipta.

Asruchin, M. (2018). Konfusianisme: sumber peradaban China. The First International Seminar \& Roundtable Meeting "Professional Chinese Teaching" In Southeast Asia, 9-11.

Cangianto, A. (2015). Pandangan filosofis tionghoa memandang mati bagaikan hidup. Extension Course Filsafat (ECF), 2.

Cheng'en, W. (2008). Journey to The West. Foreigh Languages Press.

Hartati, D. (2016). Konfusianisme dalam kebudayaan Cina modern. Paradigma, Jurnal Kajian Budaya, 2(2), 174. https://doi.org/10.17510/ paradigma.v2i2.25

Haryatmoko. (2019). Critical discourse analysis (analisis wacana kritis) : landasan teori, metodologi dan penerapan. Rajawali Pers.

Husna, T. (2020). Klenteng Kwang Sing Bio di Kelurahan Karangsari, Kecamatan Tuban, Kabupaten Tuban, Jawa Timur (Sejarah, struktur dan fungsi serta potensinya sebagai sumber belajar sejarah di SMA). Candra Sangkala, 2(2), 1-12. https:/ / doi.org/10.23887/jcs.v2i2.28811

Konfusius. (2018). Confusius : the Analek. PT. Elex Media Komputindo.

Laila, A. A. (2017). Kepercayaan Jawa dalam novel Wuni karya Ersta Andantino (Interpretatif Simbolik Clifford Geertz). Bapala, 4(1), 1-10.

Lestari, A. D., \& Indarti, T. (2018). Representasi kebudayaan Bali dalam Novel" Di Bawah Langit yang Sama" Karya Helga Rif (kajian interpretatif simbolik Clifford Geertz). Bapala, 5(2), 1-10.

Li, X. (2007). An explanation of the Confucian idea of difference. Frontiers of Philosophy in China, 2(4), 488-502. https:/ / doi.org/10.1007/s11466-0070031-1

Meher, M. A. (2019). Konfusius (A. R. P.putra (ed.)). Penerbit Basabasi.

Miles, Matthew B., A. M. H. (1992). Analisis data kualitatif: buku sumber tentang metode-metode baru (T. R. Rohidi (ed.)). Penerbit Universitas Indonesia. 
Melinda Rahmawati, Yustiara Nuraini, Bimo Rafi Widianto, Debi Robi Yanti, Sulaeman - Determinasi Konfusianisme dalam Analisis Wacana Kritis Novel Klasik "Journey to the West"

Muas, R. T. N. M. E. (2020). Konfusianisme Sebagai sabuk pengaman RRT. Paradigma, Jurnal Kajian Budaya, 10(2). https://doi.org/10.17510/PARADIGMA.V10I2.306

Pattiasina, J. (2021). Sejarah Etnis Tionghoa dalam dinamika sosial masyarakat pulau buru. Jurnal Lani : Kajian Ilmu Sejarah Dan Budaya, 2(1), 1689-1699.

Plc, L. P. (2006). Agama-agama dunia. Penerbit Kanisius.

Ramadhani, M. (2018). Pakaian anak nagari dalam Batarewai: suatu kajian interpretivisme simbolik. Universitas Negeri Padang.

Rosidi, A. (2015). Aktualisasi ajaran konfusianisme dalam membangun nasionalisme etnis tionghoa. Jurnal SMART, 01(02), 165-175.

Rozie, F. (2012). Negeri sejahtera ala konfusianisme. Kalam : Jurnal Studi Agama Dan Pemikiran Islam, 6(1), 177-196.

Singgih, M. (2016). Tridharma selayang pandang. Perkumpulan Tridharma (Sam Kauw Hwee/San Jiao Hui).

Tenggok, M. I. (2017). Agama dan kebudayaan orang Hakka di Singkawang memuja leluhur dan menanti datangnya rezeki. PT. Kompas Media Nusantara.

Zarkasih, A. (2014). Mengenal pokok-pokok ajaran Kong Hu Cu. Al-Adyan, 9(1), $21-35$. 